\title{
B cell lymphokines in human systemic lupus erythematosus
}

\author{
PAUL L J TAN, MARION BLUMENSTEIN, SUSAN YEOMAN, AND \\ JAMES D WATSON
}

From the Department of Immunobiology, University of Auckland, School of Medicine and Department of Rheumatology, Auckland Hospital, Auckland, New Zealand

SUMMARY B lymphocytes of patients with systemic lupus erythematosus were studied to determine if they were intrinsically hyperresponsive to lymphokine mediators. Peripheral blood $B$ cells from 25 lupus patients and 16 normal individuals matched for age and sex were cultured with recombinant lymphokines. $B$ cells both from patients and normal subjects did not show increased $\left[{ }^{3} \mathrm{H}\right]$ thymidine uptake when cultured with interleukins 1,2 , and 4 . The addition of Staphylococcus aureus Cowan I as costimulant increased $\left[{ }^{3} \mathrm{H}\right]$ thymidine uptake by B cells of patients and normal subjects. In the absence of $\mathrm{T}$ cells these recombinant lymphokines did not increase in vitro IgG or IgM production by lupus or normal B cells. Other recombinant lymphokines, interleukin 3, interferon gamma, lymphotoxin, tumour necrosis factor, and colony stimulating factors for granulocytes and macrophages were tested on lymphocytes from smaller numbers of patients and controls. Most patients in this study had inactive disease and all data suggested that B cells from patients with inactive lupus were not hyperresponsive to the lymphokines tested. In addition, the use of lymphokine gene probes for interleukins 2,3 , and 4 did not show spontaneous expression of these genes in circulating lymphocytes.

Lymphokines are polypeptide mediators of many functions of activated lymphocytes. ${ }^{1-3}$ Lymphokines produced by $T$ cells may influence the $T$ cells themselves or other $T$ cells, B cells, monocytes, killer cells, and non-lymphoid cells. Many known lymphokines have been cloned and are designated by an interleukin number. Although each lymphokine was initially identified by a particular biological activity, most have overlapping effects on several cell types. Conversely, the function of each lymphoid cell is affected by more than one lymphokine. B lymphocytes, for example, respond to several of the interleukins, including interleukin 1 (a leucocyte activating factor with multiple biological effects on several cell types), interleukin 2 ( $T$ cell growth factor also èffective on B cells and killer cells), interleukin 4 (B cell stimulating factor I), interleukin 5 (B cell growth factor II), interleukin 6 (B cell differentiating factor), and interferon. ${ }^{2}$

Accepted for publication 27 February 1989.

Correspondence to Dr Paul L J Tan. Department of Immunobiology, University of Auckland, School of Medicine, Private Bag. Auckland, New Zealand.
Because of their biological actions lymphokines are likely to contribute to the immune activity in diseases such as systemic lupus erythematosus (SLE). Increased levels of interferon gamma activity in serum correlate with lupus disease activity. ${ }^{4}$ On the other hand, murine and human lupus lymphocytes produce less of other regulatory lymphokines, such as interleukin 2 , and are less responsive to interleukin 2 in vitro. ${ }^{5-7}$

As the lupus syndrome is not homogeneous the $B$ cells of some lupus mice, such as the NZB/W and BXSB mice, but not the MRL/1 strain, appear hyperresponsive to mitogens and lymphokines. ${ }^{8}$ In the MRL/1 strain, abnormalities of B cell function are secondary to $\mathrm{B}$ cell differentiating lymphokines produced in excess by $\mathrm{T}$ cells. ${ }^{8}$ It may be useful to categorise lupus patients according to whether their B lymphocytes are hyperresponsive to certain lymphokines. We have examined the responsiveness of peripheral blood B lymphocytes from lupus patients to recombinant lymphokines. We have also used lymphokine gene probes to study the expression of lymphokine genes in SLE. 


\section{Patients and methods}

PATIENTS AND NORMAL CONTROLS

Twenty five patients (19 women, six men) with definite SLE as defined by the 1982 American Rheumatism Association criteria and a control group (12 women, four men) matched for age and sex were studied. ${ }^{9}$ The mean (SD) age of the patients, was $43.3(12.3)$ years and of the controls $36 \cdot 1(10 \cdot 8)$ years. They were assessed clinically and had samples taken for urine microscopy and blood taken for haemoglobin, leucocyte differential and platelet counts, antinuclear and anti-DNA antibodies, complement $\mathrm{C} 3$ and $\mathrm{C} 4$ concentrations. All drugs taken were recorded. Patients were scored for disease activity according to Urowitz's lupus activity criteria count. ${ }^{10}$ A score of 2 or more constitutes active disease, the maximum possible score being 7 . The 16 normal volunteers matched for age and sex were recruited from hospital staff.

LYMPHOCYTE PREPARATION AND CULTURE Peripheral blood lymphocytes were isolated by Ficoll-Hypaque density gradient centrifugation of heparinised blood. $T$ cells were removed from the lymphocytes by rosetting $\mathrm{T}$ cells with 2-aminoethylisothiouronium bromide treated sheep erythrocytes and fractionating on Ficoll-Hypaque density gradients. The $\mathrm{T}$ cell depleted fractions (referred to as B cells) contained less than $5 \%$ rosette positive cells. ${ }^{11}$

The proliferation of $B$ cells was assayed by microculture of $10^{5} \mathrm{~B}$ cells in $200 \mu \mathrm{l}$ of complete medium constituted by RPMI medium, $5 \%$ fetal calf serum, $100 \mathrm{IU} / \mathrm{ml}$ penicillin, $100 \mu \mathrm{g} / \mathrm{ml}$ streptomycin, and $2 \mathrm{mM}$ glutamine. $\left[{ }^{3} \mathrm{H}\right]$ Thymidine was added for the final 16 hours of the 72 hour culture. Uptake of $\left[{ }^{3} \mathrm{H}\right]$ thymidine in counts per minute (cpm) was determined by liquid scintillation. Mean cpm were derived from triplicate cultures.

B cells were also cultured at $2 \times 10^{5}$ cells in $200 \mu \mathrm{l}$ complete medium for seven days. Supernatants from triplicate cultures were harvested. Total IgG and IgM were determined by enzyme linked immunosorbent assay (ELISA) using alkaline phosphatase conjugated goat antihuman IgG or IgM (Tago, Ca, USA). Optical density readings at $404 \mathrm{~nm}$ were measured against standard curves with affinity purified human IgG or IgM (Tago, USA).

When relevant mitogens and recombinant lymphokines were added at the beginning of culture pokeweed mitogen (Calbiochem, USA) was used at a final concentration of $1 \%$ and heat killed Staphylococcus aureus Cowan I (Calbiochem, USA) fixed in formalin was used at $10^{-5} \mathrm{v} / \mathrm{v}$. All recombinant lymphokines were used at final concentrations of $0.05 \mu \mathrm{g} / \mathrm{ml}$ interleukin $1,1000 \mathrm{units} / \mathrm{ml}$ interleukin 2,
500 units $/ \mathrm{ml}$ interleukin 3, 1:10 000 dilution inteP. leukin 4 stock supernatant, 100 units $/ \mathrm{ml}$ interferoh gamma, 100 units/ml tumour necrosis factor $\overrightarrow{\mathrm{f}_{\text {, }}}$, 100 units $/ \mathrm{ml}$ lymphotoxin, 100 units $/ \mathrm{ml}$ granulocyfte colony stimulating factor, and $0.03 \mu \mathrm{g} / \mathrm{ml}$ granulocyte/ macrophage colony stimulating factor. Final conce $\bar{j}^{2}$ trations of mitogens and lymphokines were predetermined as optimal in preliminary experiments.

LYMPHOKINE GENE EXPRESSION

Total cellular RNA was isolated from human tonsil cells or peripheral blood lymphocytes by guanidiniu码 isothiocyanate, phenol-chloroform extractios, and ethanol precipitation procedures. ${ }^{12}$ Polymessenger RNA (mRNA) was prepared using oligo-dT cellulose column. About 3-5 $\mu$ g mRNQ per lane was electrophoresed on a $1 \%$ agaroseformaldehyde gel, blotted onto Genescreen Plus (NEN), and hybridised in $50 \%$ formamide, $1 \%$ sodium dodecyl sulphate, $1 \mathrm{M} \mathrm{NaCl}, 10 \%$ dextră sulphate, $600 \mu \mathrm{g} / \mathrm{ml}$ denatured salmon sperm DNA and $1-4 \times 10^{5} \mathrm{dpm} / \mathrm{ml}$ denatured probe at $42^{\circ}$ overnight. All cDNA probes were labelled with ${ }^{3}$ 隽 by random priming. Filters were washed in $2 \times$ SS $\left(0.15 \mathrm{M} \mathrm{NaCl}+0.015 \mathrm{M}\right.$ sodium citrate) and $1 \Phi_{\circ}$ sodium dodecyl sulphate at $60^{\circ} \mathrm{C}$, baked at $8 \mathrm{C}^{\circ} \mathrm{E}$ and exposed on Kodak XAR-5 $x$ ray film.

\section{Results}

CLINICA L DATA

Most of the 25 patients were in the inactive phase of their disease when scored according to the lup activity criteria count. ${ }^{10}$ The mean score for patients was 0.5 (SD 0.8). By this criterion five patients had active disease with a score of 2 . Three of these five were treated with prednisone (one patient), chlor quine (one), or azathioprine (one). Of the $2 \theta$ patients who had inactive disease (score of 1 or less:, 15 were treated with prednisone (11 patients), chloroquine (two), methotrexate (one), $\beta$ blockêr (one), phenytoin (one), and non-steroidal anginflammatory drugs (two).

GROWTH RESPONSE

$T$ cell depleted peripheral blood lymphocytes we cultured for three days with medium alone or interleukins 1,2 or 4 , and assayed for $\left[{ }^{3} \mathrm{H}\right]$ thymidifos uptake. The uptake of $\left[{ }^{3} \mathrm{H}\right]$ thymidine by $B$ lympho kines of patients and controls was similar in the absence or presence of any of these lymphokines (Table 1). The addition of $S$ aureus Cowan I costimulant to similar cultures significantly increased $\left[{ }^{3} \mathrm{H}\right]$ thymidine uptake by $B$ cells of patients and controls. In the presence of $S$ aureus Cowan? growth response was on average higher with aH three lymphokines than in their absence, bogt 
Table $1 \quad B$ cell $l^{3} H$ thymidine uptake $(\mathrm{cpm})$. Values are mean $(S D)$

\begin{tabular}{|c|c|c|c|c|}
\hline & \multicolumn{4}{|c|}{ Recombinant lymphokines } \\
\hline & None & $I L-I^{*}$ & $I L-2$ & $I L-4$ \\
\hline \multicolumn{5}{|l|}{ No mitogen } \\
\hline Control & $465 \quad(291)$ & $431 \quad(243)$ & 1358 (1299) & $480 \quad(315)$ \\
\hline SLE* & 524 (295) & 551 (377) & $1198(920)$ & 537 (484) \\
\hline \multicolumn{5}{|l|}{$\mathrm{SAC}^{*}$} \\
\hline Control & $3126(3184)$ & $4493(2725)$ & $5078(4503)$ & $3342(2300)$ \\
\hline SLE & 2988 (4697) & $4743(5349)$ & 4449 (5238) & $3021(3754)$ \\
\hline
\end{tabular}

*IL=interleukin; SLE=systemic lupus erythematosus; SAC= Staphylococcus aureus Cowan I.

there was a wide variation between individuals. Experiments with other lymphokines, including interferon gamma, granulocyte colony stimulating factor, granulocyte/macrophage colony stimulating factor, lymphotoxin and tumour necrosis factor, also showed no differences between patients and controls (data not shown).

\section{IMMUNOGLOBULIN PRODUCTION}

Peripheral blood $B$ cells were also cultured for seven days with medium or interleukins 1,2 , or 4 and assayed for immunoglobulin production. Without $T$ cells normal and lupus B cells produced similar amounts of IgG or IgM in the absence or presence of any of these lymphokines (Tables 2 and 3 ).

For the production of immunoglobulin in vitro costimulants such as pokeweed mitogen and $S$ aureus Cowan I act as T cell dependent mitogens. ${ }^{13-15}$ When pokeweed mitogen or $S$ aureus

Table 2 B cell IgG secretion (mean (SD) optical densitv at $404 \mathrm{~nm})^{*}$

\begin{tabular}{|c|c|c|c|c|}
\hline & \multicolumn{4}{|c|}{ Recombinant lymphokines } \\
\hline & None & $I L-1 \dagger$ & $I L-2$ & $I L-4$ \\
\hline \multicolumn{5}{|c|}{ No mitogen } \\
\hline Control & $0.52(0 \cdot 18)$ & $0 \cdot 36(0 \cdot 15)$ & $0 \cdot 37(0 \cdot 29)$ & $0.33(0.23)$ \\
\hline SLE $†$ & $0 \cdot 28(0 \cdot 10)$ & $0.22(0.07)$ & $0 \cdot 18(0 \cdot 07)$ & $0 \cdot 14(0 \cdot 13)$ \\
\hline \multicolumn{5}{|l|}{ PWM† } \\
\hline Control & $0 \cdot 65(0 \cdot 27)$ & $0.49(0.21)$ & $0.40(0 \cdot 17)$ & $0.39(0.26)$ \\
\hline SLE & $0 \cdot 24(0 \cdot 13)$ & $0 \cdot 17(0 \cdot 11)$ & $0 \cdot 17(0 \cdot 12)$ & $0 \cdot 16(0 \cdot 12)$ \\
\hline \multicolumn{5}{|l|}{ SAC $†$} \\
\hline Control & $0 \cdot 26(0 \cdot 39)$ & $0 \cdot 21(0 \cdot 27)$ & $0 \cdot 20(0 \cdot 21)$ & $0 \cdot 18(0 \cdot 24)$ \\
\hline SLE & $0 \cdot 18(0.08)$ & $0.13(0.06)$ & $0 \cdot 11(0 \cdot 05)$ & $0.08(0.06$ \\
\hline
\end{tabular}

* These optical density measurements indicate a range of $\operatorname{lgG}$ of $10-100 \mu \mathrm{g} / 1$.

†IL=interleukin: SLE=systemic lupus erythematosus: $P W M=$ pokeweed mitogen; $\mathrm{SAC}=$ Staphylococcus aureus Cowan I.

Data are for three controls and five patients.
Table 3 B cell IgM secretion (mean (SD) optical density at $404 \mathrm{~nm})^{*}$

\begin{tabular}{lllll}
\hline \multicolumn{5}{c}{ Recombinant lymphokines } \\
\cline { 2 - 5 } & None & $I L-1 \dagger$ & $I L-2$ & $I L-4$ \\
\hline No mitogen & & & & \\
Control & $0.37(0.18)$ & $0.26(0.12)$ & $0.20(0 \cdot 11)$ & $0.38(0.08)$ \\
SLE $\dagger$ & $0.33(0.12)$ & $0.33(0.12)$ & $0.37(0 \cdot 13)$ & $0.23(0.08)$ \\
PWM $\dagger$ & & & & \\
Control & $0.33(0.15)$ & $0.36(0.17)$ & $0.28(0.13)$ & $0.33(0.16)$ \\
SLE & $0.57(0.20)$ & $0.43(0.16)$ & $0.52(0.20)$ & $0.41(0.16)$ \\
SAC $\dagger$ & & & & \\
Control & $0.25(0.45)$ & $0.25(0.36)$ & $0.20(0.32)$ & $0.24(0.25)$ \\
SLE & $0.34(0.12)$ & $0.42(0.25)$ & $0.38(0.15)$ & $0.27(0.15)$ \\
\hline
\end{tabular}

*These optical density measurements indicate a range of IgM of $1-20 \mu \mathrm{g} / \mathrm{l}$.

†For abbreviations see Table 2.

Data are for three controls and five patients.

Cowan I was added to the cultures IgG and IgM secretion by normal B cells was not significantly increased; lupus B cells produced more IgM with pokeweed mitogen than without (row $4 v$ row 2 in Table 3), but the increase was insignificant.

B cell cultures which contained the combination of a mitogen with any of the three lymphokines also showed no increased IgG or IgM concentrations in the supernatants. In the absence of $T$ cells the range of immunoglobulin production was only $10-100 \mu \mathrm{g} / \mathrm{l}$ for IgG and 1-20 $\mu \mathrm{g} / \mathrm{l}$ for IgM whether or not a lymphokine or mitogen was present.

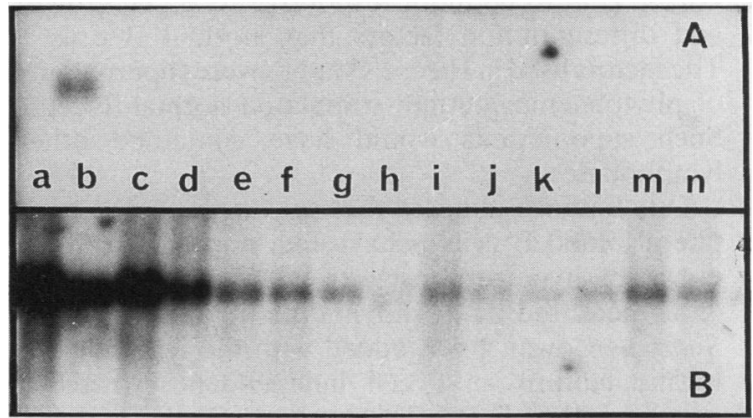

Fig. 1 Interleukin 4 gene expression (panel $A$ ). Poly- $A$ mRNA was prepared from human tonsil cells after 48 hours' culture with medium (lane a) or $1 \%$ phytohaemagglutinin and $0.5 \mu \mathrm{g} / \mathrm{ml}$ phorbol myristate (lane $b$ ), and also from fresh peripheral blood lymphocytes of normal individuals (lanes $c-f$ ) and lupus patients (lanes $g-n$ ). The approximate size of the transcript identified by hybridisation with the human interleukin 4 gene probe was $1 \mathrm{~kb}$ (lane $b$, panel A) and with the control human $\beta$-actin gene probe was $2 k b$ (panel B). 
LYMPHOKINE GENE EXPRESSION

Messenger RNA from peripheral blood lymphocytes of lupus patients and normal controls was probed with interleukins $2,3,4$, and human $\beta$-actin gene probes. Figure 1 shows the presence of mRNA specific for interleukin 4 in mitogen activated human tonsil cells. No mRNA specific for these lymphokines was detectable in peripheral blood lymphocytes from eight lupus patients and four normal subjects. Three of these lupus patients had lupus activity criteria count scores indicating active disease. When the same blots were rehybridised with the interleukin 2 and interleukin 3 gene probes the results were similar to the interleukin 4 hybridisation (not shown).

\section{Discussion}

B lymphocyte hyperactivity is a common feature of SLE. ${ }^{16}$ In murine lupus the underlying basis, genetic, cellular, or lymphokine, varies from one lupus prone strain to another. ${ }^{8}$ In human lupus it is unclear how much of the $B$ cell hyperactivity is due to an intrinsic hyperresponsiveness of B cells to various activators or lymphokines, or is secondary to $\mathrm{T}$ cell activation.

Several workers have reported a reduction in interleukin 1, interleukin 2 , and B cell growth factor (interleukin 4) production and a normal or increased B cell differentiation factor (interleukin 6) production by lymphocytes of patients with SLE. ${ }^{17-20}$ Unfractionated peripheral blood lymphocytes of lupus patients were found to be less responsive to interleukins 1 and 2. Lupus B cells were reported by Hirose et al to be more responsive to B cell growth and differentiation factors than normal $B$ cells. ${ }^{18}$ The factors used in Hirose's studies were supernatants of phytohaemagglutinin stimulated normal $\mathrm{T}$ cells. Such supernatants would have contained other lymphokines.

Our findings indicate that $(a)$ unstimulated peripheral blood B cells behave like normal B cells in not being hyperresponsive to interleukins 1,2 , and 4 , as measured by $\left[{ }^{3} \mathrm{H}\right]$ thymidine uptake; $(b)$ when $S$ aureus Cowan I was added with the lymphokines to the cultures a $T$ cell independent growth of normal and SLE B cells occurred. Of the lymphokines tested, interleukin 2 particularly enhanced the growth response of B lymphocytes, and there was no difference between lupus and normal B cells; (c) immunoglobulin production in vitro is $\mathrm{T}$ cell dependent. Using pokeweed mitogen or $S$ aureus Cowan $I$, we were unable to replace $T$ cells with interleukins 1,2 , or 4 as in vitro costimulators of IgG or IgM production by normal or lupus B cells; (d) using interleukin 2 and interleukin 4 gene probes, we could not detect spontaneous expression of these genes in peripheral blood lymphocytes.

Observed abnormalities in responses of lymphocytes taken from patients with active disease may be $\stackrel{\vec{P}}{\rightarrow}$ secondary to the disease process rather than a defect? intrinsic to individuals with the disease. Most patients $\frac{\overline{\bar{c}}}{\overline{\mathrm{s}}}$ in this study had inactive SLE as shown by their $\vec{\Phi}_{\bar{D}}$ lupus activity criteria count scores; in vivo activation $\cong$ of lymphocytes was minimised. Thus with symptoms, ڤొ clinical signs, and routine immunological variables $-\vec{\circ}$ (lymphocyte counts, serum immunoglobulin concentrations, complement concentrations) normalised, $\vec{\omega}$ lupus B cells behaved as normal B cells. The T cells also did not express increased amounts of lymphokine mRNA at a level detectable by our assays. Five patients had active SLE, but their ${ }_{-}^{\infty}$ lymphocytes were not hyperresponsive either. This. study included five patients (two with active disease + and three inactive disease) who were not taking any $\overrightarrow{0}$ drugs when their lymphocytes were obtained. Data from treated and untreated patients were similar. $\bar{Z}$ There was a wide variation in the in vitro $\left[{ }^{3} \mathrm{H}\right]$ thy-o midine uptake and immunoglobulin production by normal lymphocytes, and data from lupus B lympho-o cytes were within this variation. The responses of lupus B cells were similar to normal B cells oveôa 10 -fold dilution of lymphokines (data not show These assays did not identify subsets of patientsọn whom prompt treatment aimed at reconstituting inhibiting the effects of specific lymphokines might be indicated.

It is possible that B cells in the spleen, lympho nodes, or inflamed tissues, rather than circulating cells, are the hyperresponsive subset. Lymphokines gene expression in T cells may be transitory and thus difficult to demonstrate in randomly collected blood samples. Other lymphokines not tested-for. example, interleukin 6 , or not yet discovered, of other $B$ cell activation mechanisms involving B precursor cells may be responsible for lupus B celB. hyperactivity. ${ }^{21}$ Probably, also, in SLE the relevant $\mathrm{B}$ cell clones respond normally to lymphokines or as combination of different lymphokine mediators These lymphokines are produced appropriately by $\mathrm{T}$ cells activated by whatever triggers the immun system in this disease.

We thank Ms Anne Cherry for technical assistance. This work was supported by the Auckland Medical Research Foundation and the Arthritis Foundation of New Zealand. All recombinant lymphov kines and cDNA probes were a gift from Immunex, USA.

\section{References}

1 Gillis S, ed. Recombinant lymphokines and their receptors. Ne York: Marcel Dekker, 1987. (Immunology series, Vol 35.)

2 O'Garra A, Umland S, De France T, Christiansen J. B ceif factors are pleiotropic. Immunol Today 1988; 9: 45-54.

3 Watson J D, Tan P. Role of lymphokines in the immun 
response. In: Brooks P M, York J R, eds. Rheumatology 85 . Amsterdam: Elsevier, 1985: 27-32.

4 Hooks J J, Moutsopoulos H M, Geis S A, Stahl N I, Decker J L, Notkins A L. Immune interferon in the circulation of patients with autoimmune disease. $N$ Engl J Med 1979; 301: 5-8.

5 Dauphinee M J, Kipper S B, Wofsy D, Talal N. Interleukin 2 deficiency is a common feature of autoimmune mice. J Immunol 1981; 127: 2483-7.

6 Alcocer-Varela J, Alarcon-Segovia D. Decreased production of and response to interleukin 2 by cultured lymphocytes from patients with systemic lupus erythematosus. J Clin Invest 1982; 69: 1388-92.

7 Linker-Israeli M, Bakke A C, Quisimorio F P Jr, Horwitz D A. Correction of IL-2 production in patients with systemic lupus erythematosus by removal of spontaneously activated suppressor cells. J Clin Invest 1985; 75: 762-8.

8 Prud'homme G J, Fieser T M, Dixon F J, Theofilopoulos A N. $\mathrm{B}$ cell-tropic interleukins in murine systemic lupus erythematosus 1. Immunol Rev 1984; 78: 159-83.

9 Tan E M, Cohen A S, Fries J T, et al. The 1982 revised criteria for the classification of systemic lupus erythematosus. Arthritis Rheum 1982; 25: 1271-7.

10 Urowitz M B, Gladman D D. Tozman E C S, Goldsmith C H. The lupus activity criteria count (LACC). J Rheumatol 1984; 11: 783-7.

11 Tan P L J, Booth R J, Prestidge R L, Watson J D, Dower S K, Gillis $\mathbf{S}$. Induction of antibody responses to influenza virus in human lymphocyte cultures. Role of interleukin 2 . J Immunol 1985; 135: 2128-33.

12 Davis L G, Dibner M D, Battey J F. Basic methods in molecular biology. New York: Elsevier, 1986.

13 Hirano T, Kuritani Y, Kishimoto T, Yamamura Y. In vitro immune response of human peripheral lymphocytes. 1. The mechanisms involved in $\mathrm{T}$ helper functions in the pokeweed mitogen-induced differentiation and proliferations of $\mathrm{B}$ cells. J Immunol 1977; 119: 1235-41.

14 Saiki O, Ralph P. Induction of human immunoglobulin secretion. II. T lymphocyte dependency and radiosensitivy of T-cell help for induction of B-cell differentiation by Staphylococcus aureus strain Cowan I. Cell Immunol 1982; 70: 301-10.

15 Tan $\mathrm{P}$, Pang G, Wilson $\mathrm{J}$ D. Immunoglobulin production in vitro by peripheral blood lymphocytes in systemic lupus erythematosus: helper $\mathrm{T}$ cell defect and $\mathrm{B}$ cell hyperactivity. Clin Exp Immunol 1981; 44: 548-54.

16 Steinberg A D, Raveché E S, Laskin C A, et al. Systemic lupus erythematosus: insights from animal models. Ann Intern Med 1984; 101: 810-24.

17 Kumagai S, Sredni B, House S, Steinberg A D, Green I. Defective regulation of $B$ lymphocyte colony formation in patients with systemic lupus erythematosus. J Immunol 1982; 128: $258-62$.

18 Hirose T, Hara M, Kitani A, et al. Abnormal production of and response to B cell growth factor and B cell differentiation factor in patients with systemic lupus erythematosus. Scand J Immunol 1985; 21 : 141-50.

19 Otsuka T, Okamura S, Niho Y, Kusaba T. B cell activity and regulatory $\mathrm{T}$ cell function in systemic lupus erythematosus by human B cell colony formation. J Rheumatol 1985; 12: 508-13.

20 Warrington $\mathbf{R} \mathrm{J}$. B cell differentiation factor production in systemic lupus erythematosus. $J$ Rheumatol 1988; 15: 54-8.

21 Tanaka Y, Shirakawa F, Ota T. Suzuki H, Eto S, Yamashita U. Mechanism of spontaneous activation of $B$ cells in patients with systemic lupus erythematosus. (Analysis with anti-class II antibody). J Immunol 1988; 140: 761-7. 